\title{
Uji Coba Penerapan Model Pembelajaran Kooperatif Tipe Tim Games Tournament pada Konsep Sistem Pencernaan Makanan pada Manusia Di Kelas XI IPA MAN Tasikmalaya
}

\author{
Iim Halimatul Mu'minah",* \\ ${ }^{1}$ MTs Negeri Sukaraja Kabupaten Majalengka \\ *Email: iimhalimatul_muminah@yahoo.co.id \\ Received: 17 September 2017 | Accepted: 15 Oktober 2017| Published: 25 Desember 2017
}

\section{ABSTRAK}

Tujuan penelitian ini adalah untuk mengetahui kecocokan model pembelajaran kooperatif tipe team games tournament jika diterapkan pada proses pembelajaran konsep Sistem Pencernaan Makanan pada Manusia di kelas XI IPA MAN Tasikmalaya. Metode yang digunakan dalam penelitian ini adalah pre-eksperimen. Instrumen yang digunakan dalam penelitian ini adalah berupa soal pilihan ganda sebanyak 50 soal dengan lima option. Populasi dalam penelitian ini adalah seluruh peserta didik kelas XI IPA MAN Tasikmalaya sebanyak 2 kelas, dengan jumlah peserta didik sebanyak 35 orang yaitu 10 orang laki-laki dan 25 orang perempuan. Sampel diambil dengan menggunakan teknik sampling jenuh. Dari hasil penelitian, pengolahan, dan analisis data menunjukkan bahwa terdapat perbedaan antara hasil pretest dan posttest. Selain itu pula dari hasil uji $t$ diperoleh thitung 2,99 dan -ttabel -1,69. Hal tersebut disebabkan oleh penerapan model pembelajaran kooperatif tipe team games tournament yang membantu peserta didik dalam proses pembelajaran, karena pada dasarnya model pembelajaran kooperatif tipe team games tournament menekankan pada daya ingat, keaktifan dan pemahaman peserta didik terhadap suatu materi. Dengan demikian dapat disimpulkan bahwa model pembelajaran kooperatif tipe team games tournament cocok diterapkan untuk menjelaskan konsep Sistem Pencernaan Makanan pada Manusia di kelas XI IPA MAN Tasikmalaya.

Kata kunci: model pembelajaran; Pengetahuan; kooperatif tipe team games tournament; hasil belajar

Copyright $(92018$ BIOEDUSCIENCE All rights reserved

\section{PENDAHULUAN}

Dunia pendidikan kita ditandai leh disparitas atau perbedaan antara pencapaian academic standard dan performance standard. Faktanya, banyak peserta didik mampu menyajikan tingkat hapalan yang baik terhadap materi ajar yang diterimanya, namun pada kenyataanya mereka tidak memahaminya. Sebagian besar peserta didik tidak mampu menghubungkan antara apa yang mereka pelajari dengan bagaimana pengetahuan tersebut digunakan/dimanfaatkan. Peserta didik memiliki kesulitan untuk memahami konsep akademik sebagai mana mereka biasa diajarkan yaitu dengan menggunakan sesuatu yang abstrak dan metode ceramah. Aktifitas kegiatan belajar mengajar selama ini merupakan pseudo pembelajaran. Terdapat jarak cukup jauh antara materi yang dipelajari dengan peserta didik sebagai insan yang mempelajarinya. Sebagai medium pendekat antara materi dan peserta didik pada pembelajaran artificial adalah aktivitas mental berupa hafalan.

Pembelajaran lebih menekankan memorisasi terhadap materi yang dipelajari daripada struktur yang terdapat di dalam materi itu. Pembelajaran seperti ini melelahkan dan membosankan. Pembelajaran yang kurang efektif tersebut menyebabkan masih ada beberapa 
peserta didik yang menunjukan kurangnya pemahaman peserta didik dalam mata pelajaran Biologi sehingga tidak mampu memecahkan dan menyelesaikan soal-soal yang diberikan. Hal ini dapat dilihat dari hasil rata-rata nilai ulangan pada konsep Sistem Pencernaan Makanan pada Manusia yang diperoleh peserta didik kelas XI IPA MAN Tasikmalaya pada tahun ajaran 2011/2012 hanya mencapai 65,25 sedangkan Kriteria Ketuntasan Minimal (KKM) yang di tetapkan adalah 73,00.

Untuk mengatasi permasalahan tersebut, guru perlu mengembangkan model pembelajaran yang telah ada atau bahkan menggantinya. Salah satunya dengan mencoba menerapkan model pembelajaran kooperatif. Model pembelajaran kooperatif didefinisikan sebagai falsafah mengenai tanggung jawab pribadi dan sikap menghormati sesama. Peserta didik bertanggung jawab atas belajar mereka sendiri dan berusaha menemukan informasi untuk menjawab pertanyaan-pertanyaan yang dihadapkan pada mereka. Guru bertindak sebagai fasilitator, memberikan dukungan tetapi tidakmengarahkan kelompok ke arah hasil yang sudah disiapkan sebelumnya. Bentuk-bentuk assessment oleh sesama peserta didik di gunakan untuk melihat hasil prosesnya.

Pembelajaran kooperatif adalah konsep yang lebih luas meliputi semua jenis kerja kelompok termasuk bentuk-bentuk yang lebih dipimpin oleh guru atau diarahkan oleh guru. Secara umum pembelajaran kooperatif dianggap lebih diarahkan oleh guru, dimana guru menetapkan tugas dan pertanyaan-pertanyaan serta menyediakan bahan-bahan dan informasi yang dirancang untuk membantu peserta didik menyelesaikan masalah yang dimaksud. Guru biasanya menetapkan bentuk ujian tertentu pada akhir tugas.

Pada pembelajaran kooperatif, peserta didik diberi kesempatan untuk berkomunikasi dan beriteraksi sosial dengan temannya untuk mencapai tujuan pembelajaran. Artinya dalam pembelajaran ini kegiatan aktif dengan pengetahuan dibangun sendiri oleh peserta didik dan mereka bertanggung jawab atas hasil pembelajarannya.

Pembelajaran kooperatif memiliki beberapa tipe model pembelajaran, pada penelitian ini penulis mencoba menggunakan model pembelajaran kooperatif tipe team games tournament. Model pembelajaran kooperatif tipe team games tournament adalah salah satu tipe atau model pembelajaran kooperatif yang mudah diterapkan, melibatkan aktivitas seluruh peserta didik tanpa harus ada perbedaan status, melibatkan peran peserta didik sebagai tutor sebaya dan mengandung unsur permainan serta reinforcement.

Aktifitas belajar dengan permainan yang dirancang dalam pembelajaran kooperatif model team games tournament memungkinkan peserta didik dapat belajar lebih relaks di samping menumbuhkan tanggung jawab, kerja sama, persaingan sehat dan keterlibatan belajar, karena pada model pembelajaran ini diadakan kompetisi terhadap timnya dengan memberikan point-point agar skor tim mereka mendapatkan yang terbaik.

Model pembelajaran kooperatif tipe team games tournament melatih peserta didik untuk mampu memecahkan masalahnya sendiri saat membaca dan menjawab pertanyaan-pertanyaan pada sebuah kartu permainan dengan dilandasi rasa tanggung jawab terhadap dirinya sendiri dan juga terhadap kelompoknya.

\section{MATERI DAN METODE}

Metode yang digunakan dalam penelitian ini adalah pre-experimental. Sugiyono (2010) mengemukakan bahwa: pre-experimental dikatakan belum merupakan eksperimen yang sunguh-sungguh, karena masih terdapat variabel luar yang ikut berpengaruh terhadap terbentuknya variabel dependen. Jadi hasil eksperimen yang merupakan variabel dependen itu bukan sematamata dipengaruhi oleh variabel independen. Hal ini dapat terjadi, karena tidak adanya variabel kontrol, dan sampel tidak dipilh secara random. Metode ini digunakan karena langsung mengadakan kegiatan belajar mengajar dengan menguji cobakan model pembelajaran yang telah 
dipilih. Penelitian yang dilakukan bertujuan untuk mengetahui kecocokan model pembelajaran kooperatif tipe team games tournament jika diterapkan pada proses pembelajaran konsep Sistem Pencernaan Makanan pada Manusia.hasil penelitian berupa angka-angka yang mempunyai makna.

Analisis data dengan menggunakan uji t untuk melihat perbedaan hasil pretest dan posttest dan untuk mengetahui apakah rata-rata hasil belajar sama atau lebih dari KKM.

\section{Sampel}

Populasi dalam penelitian ini adalah seluruh peserta didik kelas XI IPA MAN Tasikmalaya tahun ajaran 2012-2013 sebanyak dua kelas dengan jumlah peserta didik 35 orang yaitu 25 orang perempuan dan 10 orang lakilakiyang bersifat homogen dan memiliki karakteristik yang sama dilihat berdasarkan ratarata nilai ulangan Biologi. Sampel diambil dengan menggunakan teknik sampling jenuh.

Tes

Tes yang digunakan dalam penelitian adalah tes tertulis dalam bentuk pilihan ganda dengan lima option. Tes ini diberikan kepada objek penelitian yaitu peserta didik dengan materi yang akan disampaikan mengenai konsep Sistem Pencernaan Makanan pada Manusia

\section{HASIL}

\section{Pengertian Model Pembelajaran kooperatif tipe team games tournament}

Model Pembelajaran kooperatif tipe team games tournament menurut Slavin, Robert E (2009), Merupakan salah satu model pembelajaran cara penyampaian pelajarannya oleh guru dan tim kerja seperti dalam STAD, tetapi menggantikan kuis dengan turamnen mingguan, dimana peserta didik memainkan game akademik dengan tim lain untuk menyumbangkan poin bagi skor timnya, dan tim dengan tingkat kinerja tertinggi akan mendapat sertifikat atau dalam bentuk penghargaan tim lainnya. Menurut Slavin, Robert (2009),
„'Langkah-langkah model pembelajaran kooperatif tipe team games turnament adalah sebagai berikut:

\section{Persiapan materi}

Materi dalam team games tournament sama saja dengan student teams achievement divisions. Mula-mula diperkenalkan dalam presentasi kelas. Ini merupakan pengajaran langsung seperti yang sering dilakukan atau diskusi pelajaran yang dilakukan oleh guru;

\section{Menempatkan para peserta didik kedalam tim}

Tim-tim dalam team games tournament mewakili seluruh bagian di dalam kelas. Di dalam kelas terdiri dari separuh laki-laki, separuh perempuan. Langkah-langkah menempatkan peserta didik kedalam tim adalah:

a) Memfotokopi lembar rangkuman tim.

Membuat satu buah kopian dari lembar rangkuman tim setiap empat siswa dalam kelas;

b) Menyusun peringkat peserta didik

Pada selembar kertas, membuat urutan peringkat siswa di dalam kelas dari yang tertinggi sampaai yang terendah;

c) Menentukan berdasarkan tim

Menentukan tim yang akan dibentuk, jumlah siswa yang ada di kelas dibagi empat, hasil bagi tersebut tentunya merupakan jumlah tim beranggotakan empat orang dalam setiap kelompok;

d) Membagikan siswa kedalam tim

Membagi siswa kedalam Tim, seimbangkan timnya supaya tiap tim terdiri atas level yang kinerjanya berkisar dari yang rendah, sedang dan tinggi. Level kinerja yang sedang dari semua tim yang ada di kelas hendaknya setara. Gunakan daftar peringkat siswa berdasarkan kinerjanya;

e) Mengisi lembar rangkuman tim Mengisi lembar rangkuman tim dengan nama-nama siswa dari tiap tim dalam lembar rangkuman tim, biarkan tempat menulis nama siswa kosong; 


\section{Menempatkan para siswa ke dalam meja turnamen}

Membuat kopian lembar penempatan meja tournament. Tulislah daftar nama siswa dari atas kebawah sesuai urutan kinerja mereka sebelumnya, gunakan peringkat yang sama seperti yang akan anda gunakan untuk membentuk Tim. Hitunglah jumlah peserta didik di dalam kelas;

\section{Memulai team games tournament}

Pada awal periode permainan, umumkanlan penempatan meja turnamen dan mintalah para siswa untuk memindahkan meja mereka bersama atau menyusun meja sebagai meja turnamen.

Mintalah salah satu peserta didik untuk membagikan satu lembar permainan. Untuk memulai permainan menarik kartu untuk menentukan pembaca yang pertama.Pembaca pertama mengocok kartu dan mengambil kartu yang teratas. Dia lalumembacakan dengan keras soal yang berhubungan dengan nomor yang ada pada kartu. Pembaca yang tidak yakin akan jawabannya di perbolehkan menebak tanpa dikenai sanksi. Setelah sipembaca memberikan jawaban, siswa yang ada di sebelah kiri atau kanannya (penantang pertama) punya opsi untuk menantang dan memberikan jawaban yang berbeda dengan dua peserta yang pertama, maka penantang yang kedua boleh menantang. Akan tetapi, penantang harus hati-hati karena mereka harus mengembalikan kartu yang telah di menangkan sebelumnya kedalam kotak. Untuk mengetahui jawaban yang benar penantang di sebelah kanan pembaca memeriksa jawabandan membacakan jawaban yang benar dengan keras. Sipemain yang memberikan jawaban yang benar akan menyimpan kartunya. Untuk putaran berikutnya, semuanya bergerak satu posisi ke kiri : penantang pertama menjadi pembaca, penantang kedua menjadi menjadi penantang pertama, dan si pembaca menjadi penantang kedua. Apabila permainan sudah berakhir, para pemain mencatat nomor yang telah mereka menangkan pada lembar skor permainan;

\section{Menentukan skor tim}

Segera setelah turanmen selesai, tentukanlah skor tim dan persiapkansertifikat tim untuk member rekognisi kepada tim peraih skor tertinggi. Periksalah poin-poin turnamen yang ada pada lembar skor permainan. Lalu, pindahkan poin-poin turamen dari tiap siswa tersebut ke lembar rangkuman dari timnya masingmasing,tambahkan seluruh skor anggota tim, dan bagilah dengan jumlah anggota tim yang bersangkutan; dan

\section{Merekognisi tim berprestasi}

Dalam team games tournament diberikan tiga tingkatan penghargaan, yang didasarkan pada skor rata-rata tim.

\section{HASIL PENELITIAN}

Berdasarkan tes hasil belajar peserta didik kelas XI IPA MAN Tasikmalaya sebelum dan sesudah melakukan proses pembelajarandengan menggunakan model pembelajaran kooperatif tipe team games tournament pada konsep Sistem Pencernaan Makanan pada Manusia dengan jumlah butir soal sebanyak 40, diperoleh data statistik hasil belajar peserta didik sebelum melakukan proses pembelajaran dengan menggunakan model pembelajaran kooperatif tipe team games tournament (pretest) yaitu nilai minimum 19, nilai maksimum 29, rentang 10 , median 26, rata-rata 24,76, varians 9,20 dan standar deviasi 3,03. Sedangkan data statistik hasil belajar peserta didik sesudah melakukan proses pembelajaran dengan menggunakan model pembelajaran kooperatif tipe team games tournament (posstest) yaitu nilai minimum 25, nilai maksimum 35 , rentang 10 , median 31 , ratarata 30,64 , varians 8,07 , standar deviasi 2,84 .

\section{Pengujian Prasyarat Analisis}

\section{Uji Normalitas}

Hasil uji normalitas sebelum proses pembelajaran dengan menggunakan model pembelajaran kooperatif tipe team games tournament pada konsep Sistem Pencernaan 
Makanan pada Manusia yaitu terima H0. Artinya data berasal dari populasi yang berdistribusi normal. Sedangkan hasil uji normalitas sesudah proses pembelajaran dengan menggunakan model pembelajaran kooperatif tipe team games tournament pada konsep Sistem Pencernaan Makanan pada Manusia yaitu terima HO.

Maka berdasarkan kedua data dalam penelitian ini memperoleh nilai $\square 2$ hitung yang lebih kecil dari $\square$ 2tabel. Dengan demikian dapat disimpulkan bahwa, kedua data telah diambil dari populasi yang berdistribusi normal.

\section{Uji Homogenitas}

Dari data tes hasil belajar peserta didik yang proses pembelajarannya menggunakan model pembelajaran kooperatif tipe team games tournament diperoleh Fhitung 1,14 dan Ftabel 1,78. Berdasarkan hasil analisa uji homogenitas tersebut menurut perhitungan, maka didapat Fhitung $<$ Ftabel, sehingga dapat disimpulkan bahwa kedua kelompok data tersebut variansnya homogen.

\section{Pengujian Hipotesis}

Karena kedua kelompok data telah diambil dari populasi yang berdistribusi normal dan kedua kelompok data variansnya homogen, maka pengujian dilanjutkan dengan menggunakan uji t. Berdasarkan hasil uji $\mathrm{t}$ diketahui bahwa thitung $=$ $-15,15$ terletak di daerah penolakan H0. Dengan demikian hipotesis yang penulis ajukan yaitu "hasil pretest tidak sesuai dengan hasil posttest" dapat diterima. Untuk mengetahui apakah model pembelajaran kooperatif tipe team games tournament cocok diterapkan untuk menjelaskan konsep Sistem Pencernaan Makanan pada Manusia di kelas XI IPA MAN Tasikmalaya, maka dilakukan uji t. Berdasarkan perbandingan antara nilai thitung dengan nilai ttabel diperoleh thitung 2,99 dan ttabel 1,69 maka dapat disimpulkan bahwa nilai KKM telah terlewati, artinya model pembelajaran kooperatif tipe team games tournament cocok diterapkan untuk menjelaskan konsep Sistem Pencernaan Makanan pada Manusia di kelas XI IPA MAN Tasikmalaya.

Dari hasil penelitian yang telah dilakukan menunjukkan bahwa model pembelajaran kooperatif tipe team games tournament cocok diterapkan untuk menjelaskan konsep Sistem Pencernaan makanan pada Manusia di kelas XI IPA MAN Tasikmalaya. Hal itu ditunjukkan dengan hasil belajar peserta didik yang proses pembelajarannya sesudah menggunakan model pembelajaran kooperatif tipe team games tournament yang memperoleh nilai rata-rata sebesar 30,64 lebih tinggi dari hasil belajar peserta didik yang proses pembelajarannya sebelum menggunakan model pembelajaran kooperatif tipe team games tournament yang memperoleh nilai rata-rata sebesar 24,76 .

\section{KESIMPULAN}

Berdasarkan hasil pengolahan data dan pengujian hipotesis, maka penulis berkesimpulan bahwa model pembelajaran kooperatif tipe team games tournament cocok diterapkan untuk menjelaskan konsep Sistem Pencernaan Makanan pada Manusia di Kelas XI IPA MAN Tasikmalaya.

\section{DAFTAR PUSTAKA}

Arikunto, Suharsimi. 2002. Prosedur Penelitian. PT Rineka Cipta.Jakarta.

Armanadhi. 2012. Materi Kelas 8 SMP. OnlineTersedia:

http://armanadhi.blogspot.com/2012/02/materikelas-8-smp.html

Dimyati, dan Mudjiono. 2006. Belajar dan Pembelajaran. PT. Rineka Cipta. Jakarta.

Hernawan, Edi. 2012. Pengantar Satistika Parametrik untuk Penelitian Pendidikan. FKIP Universitas Siliwangi.Tasikmalaya. 